\title{
Advance directives of patients: process of implementation by palliative care teams
}

\author{
Diretivas antecipadas de vontade dos pacientes: processo de implementação por equipes de cuidados paliativos
}

Directivas anticipadas: proceso de implementación por equipos de cuidados paliativos

\section{Aline Carniato Dalle Nogario' \\ ORCID: 0000-0003-2602-2729 \\ Edison Luiz Devos Barlem' \\ ORCID: 0000-0001-6239-8657}

Jamila Geri Tomaschewski-Barlem' ORCID: 0000-0001-9125-9103

Rosemary Silva da Silveira' ORCID: 0000-0003-0671-0022

Silvana Bastos Cogo" ORCID: 0000-0002-1686-8459

Deciane Pintanela de Carvalho' ORCID: 0000-0003-1598-6602

'Universidade Federal do Rio Grande. Rio Grande, Rio Grande do Sul, Brazil. "Universidade Federal de Santa Maria. Santa Maria, Rio Grande do Sul, Brazil.

How to cite this article: Nogario ACD, Barlem ELD, Tomaschewski-Barlem JG, Silveira RS, Cogo SB, Carvalho DP. Advance directives of patients: process of implementation by palliative care teams.

Rev Bras Enferm. 2020;73(Suppl 6):e20190567. doi: http://dx.doi.org/10.1590/0034-7167-2019-0567

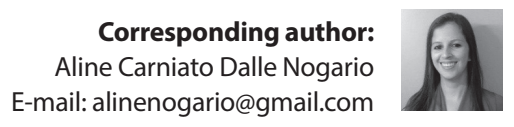

EDITOR IN CHIEF: Dulce Barbosa ASSOCIATE EDITOR: Mitzy Reichembach

Submission: 01-02-2020

Approval: 05-28-2020

\section{ABSTRACT}

Objectives: to investigate the process of implementing advance directives in palliative care teams in southern Brazil. Methods: an exploratory-descriptive study with a qualitative approach conducted with 51 professionals from seven palliative care teams from December 2018 to April 2019. Data were collected through semi-structured online interviews and submitted to discursive textual analysis. Results: the implementation process starts on approach of the advance directives with patients, so that their wishes and desires are the guiding axis for planning care and conduct. Final Considerations: the palliative philosophy is important with regard to advance directives, due to the preparation of these professionals in the search for dignity, quality of life and respect for patient autonomy, in addition to reducing suffering and offering dignified death, based on the understanding of human finitude as a natural process that belongs to life.

Descriptors: Advance Directives; Palliative Care; Ethics; Patients; Respect.

\section{RESUMO}

Objetivos: investigar o processo de implementação das diretivas antecipadas de vontade nas equipes de cuidados paliativos do Sul do Brasil. Métodos: estudo exploratório-descritivo com abordagem qualitativa, realizado com 51 profissionais de sete equipes de cuidados paliativos no período de dezembro de 2018 a abril de 2019. Os dados foram coletados através de entrevista semiestruturada online, e submetidos à análise textual discursiva. Resultados: o processo de implementação inicía na abordagem das diretivas antecipadas de vontade com pacientes, de forma que seus desejos e vontades sejam norteadores do planejamento dos cuidados e condutas. Considerações Finais: a filosofia paliativista é importante no que diz respeito às diretivas antecipadas de vontade, em função do preparo desses profissionais na busca pela dignidade, qualidade de vida e respeito à autonomia do paciente, além da redução do sofrimento e oferta de morte digna partindo da compreensão da finitude humana como processo natural e pertencente à vida.

Descritores: Diretivas Antecipadas; Cuidados Paliativos; Ética; Pacientes; Respeito.

\section{RESUMEN}

Objetivos: investigar el proceso de implementación de directivas anticipadas en equipos de cuidados paliativos en el sur de Brasil. Métodos: estudio exploratorio descriptivo con enfoque cualitativo, realizado con 51 profesionales de siete equipos de cuidados paliativos desde diciembre de 2018 hasta abril de 2019. Los datos se recopilaron através de entrevistas en línea semiestructuradas y se sometieron a análisis textual discursivo. Resultados: el proceso de implementación comienza con enfoque del tema de directivas anticipadas con los pacientes, de modo que sus deseos y deseos sean el eje guía para planificar la atención y la conducta. Consideraciones Finales: la filosofía paliativa es importante con respecto a directivas anticipadas, debido a la preparación de profesionales en la búsqueda de dignidad, calidad de vida y respeto por autonomía del paciente, además de reduciendo sufrimiento y ofreciendo muerte digna basada en la comprensión de finitud humana como proceso natural pertenece a la vida.

Descriptores: Directivas Anticipadas; Cuidados Paliativos; Ética; Pacientes; Respeto. 


\section{INTRODUCTION}

Patient care in the hospital has undergone changes due to the rapid development of biomedical sciences and technology, which has had a significant impact on the extension of life expectancy ${ }^{(1)}$. However, when technology is not satisfactory for the maintenance of human existence, the search for a cure can cause its artificial extension as well as loss of patient autonomy and even dignity ${ }^{(1)}$.

Palliative care (PC) has emerged as a new approach to situations in which patients are out of therapeutic possibilities, which confronts the different perceptions of death and the understanding that medical intervention has increasingly tenuous limits ${ }^{(2)}$. The last definition for PC was released in 2017, considering them as an approach that improves the quality of life of patients and families in coping with life-threatening diseases, seeking to prevent and alleviate suffering through identification, assessment and treatment of pain and other symptoms that affect individuals in all dimensions ${ }^{(3)}$.

In relation to $P C$ and public health policies, Resolution 41 was approved on October 31, 2018 providing for the organization of PCs within the scope of the Brazilian Health System (Sistema Único de Saúde, abbreviated SUS) and regulating its offer at any level of care $^{(4)}$. In the state of Rio Grande do Sul (RS), Law 15,277 was enacted on January 31, 2019, instituting the State Policy of Palliative Care aiming at comprehensive health care for people with life-threatening diseases ${ }^{(5)}$.

PC can be offered in various modalities such as outpatient or day hospital, home care, inns and hospitalization in units with exclusive beds for PC or in non-exclusive units where patients are assessed by consulting or itinerant teams ${ }^{(6)}$. The main aim is to promote quality of life, understanding that patients have adequate control of their symptoms, die at the right time, as well as preserving their autonomy ${ }^{(7)}$. Therefore, advance directives (AVD) are inserted in this context, which seek to legitimize the wishes of patients who face a serious or irreversible disease, through what was reported by them or by their designated representative ${ }^{(8)}$.

AVD is a kind of document that includes the living will (LW) and the lasting mandate (LM). On LW, the acceptance or refusal of treatments is documented, allowing control over health decisions when being incapable due to diseases without therapeutic possibilities ${ }^{(9-10)}$. The $L M$, on the other hand, corresponds to the appointment of a third party as a health attorney, who becomes responsible for decisions related to patients when they cannot decide for themselves ${ }^{(9)}$.

In Brazil, Resolution 1,995 was published in 2012, in which the Federal Council of Medicine (Conselho Federal de Medicina, abbreviated CFM) recognizes AVD as a document in which patients express acceptance or refusal of care and treatments to be respected when they are unable to express themselves ${ }^{(11)}$. This resolution resulted in the expansion of registered AVD, data corroborated by the increase from 81 records in 2011 to 205 records in 2012 ${ }^{(12)}$. From 2004 to 2018, Rio Grande do Sul ranked second with 551 AVD registered, and in 2017 alone 83 $\mathrm{AVD}^{(12)}$ were registered.

PC is based on honest communication between professionals, patients and their families; due to the difficulties sometimes encountered in the discussion about the problems faced at the end of life, AVD act as an open source for debate of important issues for patients involved ${ }^{(13)}$. In this context, PC is related to AVD by seeking to offer patients respect for their autonomy and dignified death.

The PC team is multidisciplinary, comprised of a physician, nurse, nursing technician, dentist, nutritionist, psychologist, social worker, religious assistant, occupational therapist, physiotherapist, speech therapist and pharmacist. It is important to consider that there will not necessarily be all professionals in all the teams. Their work may or may not be associated with curative treatment and aims to manage symptoms that are difficult to control in patients, also supporting families throughout the process of illness, death and grief ${ }^{(14)}$. The PC team can receive assistance from assistant teams, which can be formed by professionals from different categories, but without palliative training.

The choice of PC teams was due to the fact that in the palliative philosophy there is the objective of supporting and anchoring patients and their families in life-threatening disease situations; and no Brazilian studies were found correlating the approach of AVD with the practice of PC professionals. Both themes, still little known in society, are intertwined by making it possible to offer individual, humanized and dignified care to those who actively face their death process. However, in practice, professionals still face obstacles when they offer leadership to patient care.

\section{OBJECTIVES}

To investigate the process of implementing AVD in PC teams in southern Brazil.

\section{METHODS}

\section{Ethical aspects}

The study respected all precepts related to ethics in research with human beings according to Resolution 466/2012 of the Brazilian National Health Council (Conselho Nacional de Saúde); and was only started after approval of the Local Ethics Committee under Opinion and the Ethics Committees of the participating institutions through Plataforma Brasil. All participants received clarifications about the research together with the link to access the instrument and the Informed Consent Form individually.

In order to preserve the identity of the study participants, the institutions were named by letters ( $A, B, C, D, E, F$, and $G$ ) and the professionals by numbers according to the professional category (1 - nurse, 2 - physician, 3 - nursing technician, 4 - psychologist, 5 - nutritionist, 6 - speech therapist, 7 - occupational therapist, 8 - physical therapist, 9 - social worker, 10 - dentist, 11 - religious assistant, and 12 - pharmacist).

\section{Type of study}

This is a qualitative, exploratory and descriptive study according to Moraes and Galiazzi ${ }^{(15)}$.

\section{Methodological procedures}




\section{Study setting}

The study was carried out with the PC teams of seven hospital institutions in RS registered in 2018 on the website of the Brazilian National Academy of Palliative Care (Academia Nacional de Cuidados Paliativos, abbreviated ANPC): one from the city of Pelotas, one from Sapucaia do Sul, one from Santa Maria, one from Passo Fundo and three from Porto Alegre. Public or philanthropic hospitals in RS offering PC services were included in the study.

\section{Data source}

Fifty-one professionals from seven PC teams, among nurses, physicians, nursing technicians, speech therapists, occupational therapists, physiotherapists, nutritionists, dentists, religious assistants, social workers, psychologists and pharmacists, participated in the study. The inclusion criterion used was to work at least three months in the service.

\section{Data collection and organization}

The data collection period was between December 2018 and April 2019. The PC team coordinators were asked to send the professionals' emails the semi-structured online interview created by Google Forms. Google Forms made it possible for participants to type answers in open questions in order to characterize the study participant, the service and, finally, questions regarding implementation of AVDs.

\section{Data analysis}

Data were submitted to discursive textual analysis and to four stages: unitarization, categorization, capture of the new emerging and finally the self-organized process, which allowed the creation of a new understanding of the proposed theme ${ }^{(15)}$.

\section{RESULTS}

The teams presented different forms of performance: a team worked exclusively in a specific unit for PC; a team in the consulting mode and in a specific PC unit; two developed their work in consultancy, itinerant ambulatory and in specific beds of PC; and three teams exclusively with consultancy. All teams had nurses and physicians in their composition; six had psychologists, physiotherapists and social workers; five had a nutritionist and religious assistant; four had pharmacists; three had nursing technicians and two teams were trained in speech therapy, occupational therapist and dentist.

From participant characterization, it was found that of the 51 professionals, 37 were female and 14 were male; the length of experience in the profession ranged between two and 44 years. In relation to PC training, 12 professionals stated that they took improvement courses and eight specialized courses and their time in PC varied between six months and 32 years.

From data analysis, three categories emerged that define the process of implementing AVD: Approach of advance directives with patients; Registry of advance directives; and Conduct of palliative care teams and assistant teams in relation to advance directives.

\section{Approach of advance directives with patients}

Implementing AVD begins with the systematization of the ways of approaching patients and all the complexity involved, especially with regard to family support and the professional's perception of the difficulties to be faced in the process. According to the reports with regard to implementation, professionals recognized the important instruments to be used in approaching $A V D$, i.e., the first step for implementation, such as the establishment of bonds of trust with patients, effective communication with patients and approach to AVD in the family context.

The professionals mentioned that, by communicating the diagnosis, the team needs to establish a bond of trust with patients, to then assess what they understand about their health condition, their current and future needs as well as the possible perspectives, enabling the planning how issues will be inserted in their individual context:

Initially, a team member makes the initial contact to identify the demands. After the bond is formed, the approach begins. The degree of understanding of patients about their disease, prognosis and expectations is assessed [...] (C. 2.1)

I see that, first, a bond of trust is established with the patient. Over time, patients gradually enter into these issues and advance the themes, as they accept. (A.11.1)

The study participants reported that conversation takes place primarily between patients, physicians and nurses, with the other professionals being triggered according to the demand found:

Nurse and physician. (C.5.1, E.2.2, E.6.1, F.9.2)

The physician introduces, when we attend the PC clinic, and the other professionals complement, according to the demand/ situation that is presented. But in general, we all address. (C.1.1)

Professionals perceive effective communication with patients and family members as an instrument to approach AVD, but consider the need to improve it due to its importance in conducting the process. Communication planning through meetings was mentioned, one among the PC team professionals and the other carried out with family members:

In the first assessment of patients, they are asked what they want to know about their pathology (results of tests, treatment, course of the disease). In addition, it is asked how much of this information they want to receive, as well as which family members and/or circle of trust want this information to be passed on and who they indicate as people they trust by making a decision that is not described in their advance directives... (A.2.1)

Weekly meetings, a team meeting and one with family members are held. (B.9.1)

Furthermore, professionals reported that addressing AVD in the family context is a difficult time due to the conspiracy of silence and the understanding that complying with the patient's wishes can be interpreted as giving up the loved one: 
There is a lot of conspiracy of silence, but when we manage to permeate this in a peaceful way, sometimes it works. (A.2.2)

Most of the time, they accept the patient's will, other times, they think that by agreeing they are giving up on the patients. (E.12)

\section{Registry of advance directives}

With regard to registry of AVD, this step is only effective after its approach and contextualization with patients and their family. The family or a family member chosen by patients becomes responsible for the decisions when they cannot decide for themselves.

Concerning AVD records, the PC team professionals mentioned the actions implemented in their routines regarding formalization of AVD record; about the description in the medical record; transfer of information among the professionals about the wishes of patients; printed delivery to patients of AVD when considering the possibility of presenting it in later appointments as well as incentive to register in the registry office. They also mentioned using a specific questionnaire as a way to record AVD.

Medical records are perceived as important tools so that all professionals involved have access to information regarding patients, even when not present in the visits. It is a legal document that guides the conduct, which is permeated by the records made during the hospitalization period:

When there is a verbal manifestation, we try to record the evolution of the electronic medical record... (C.1.2)

In the medical record, but it is notentitled as advance directives. (A.2.2)

It was also mentioned, in addition to medical records, transfer of information among the team through the use of resources, such as messaging applications, considering the inexistence of a standard AVD registry system and that many professionals do not seek information from the medical record or can still be triggered in conflict situations without first having access to the records:

Through the evolution of palliative care teams in records of patients and also through a group of messages to the team. (B.1.2)

In relation to the use of questionnaires to record information, the POLST protocol (Physician Orders for Life Sustaining Treatment) was mentioned, which investigates end-of-life care related to cardiopulmonary resuscitation, nutrition and other interventions, being used as a way of record in the patients' records:

Direct conversation with patients; applying a specific questionnaire (POLST translated). (G.2.1)

The PC team professionals reported that AVD are also delivered in printed form to patients in an attempt to ensure that their wishes are respected later in other appointments and also encourage their registry in a registry office.

Registry is performed on medical developments in the electronic medical record. Upon discharge, it is recorded in the document, and patients are advised to take this role in all their scheduled behaviors and complications. (A.2.1)
Advance directives of patients: process of implementation by palliative care teams Nogario ACD, Barlem ELD, Tomaschewski-Barlem JG, Silveira RS, Cogo SB, Carvalho DP.

In the system attendance record and the registry is encouraged. (C.8)

\section{Conduct of palliative care teams and assistant teams in relation to advance directives}

AVD can become effective through professional intervention in order to respect what has been agreed and recorded. In the context of the teams participating in the study, participation of assistant team professionals was reported, who do not have palliative training and develop their activities in non-specific PC units. In this category, perceptions regarding relationships between PC teams and assistant teams and behaviors towards AVD emerged.

The teams participating in the study present the consulting modality as the most common form of action, assessing patients in non-specific PC units after request. Some consulting teams reported taking on the role of addressing AVD and talking about the topic with patients:

During consultation with the consultant group, and if hospitalized by the team that travels to the unit and makes the approach. (C.8.1)

As early as possible both during hospitalization and at the clinic. (E.2.3)

In contrast, other consulting teams stated that the approach is the responsibility of the assistant team, due to the understanding that they are responsible for prescribing care and monitoring during hospitalization:

As the team is a consultancy, it is hoped that the assistant team has carried out this approach. It ends up guiding the team to perform, since many professionals are unaware. (D.4.1)

PC professionals reported that they seek to respect patients' requests, even when they do not agree with their wishes, guiding them about the possibility of changing their choice:

Respect them, maintain a dialogue about possibilities and understand the reason why their decisions were made. (E.2.1)

I try to know the patient and family history, but in general, I respect the wishes of patients, even if I disagree from the clinical point of view. (C.1.2)

When questioning about the PC team's view regarding the conduct of other professionals, there were reports that assistant teams disrespect the patients' wishes and desires, whether due to disagreement, disinformation, fear of legal implications, difficulty in understanding the process of finitude or even by the understanding that professional knowledge must overlap when judging a disease situation:

Strangely and very afraid of the judicial aspects. (C.2.1)

There is a difficulty for most professionals, mainly physicians, to accept patients' wishes. Difficulty in accepting death as a natural process. (E.2.3)

Difficulty accepting the choice because they think their knowledge should overlap with what patients want. (F.2.1) 
On the other hand, it was mentioned that the assistant team professionals who seek information about the AVD registered with the PC team, come to understand the wishes of patients, positively assisting in the implementation of the desired care:

We encountered resistance in some professionals due to lack of understanding and knowledge, but when they receive clarification on the subject, they recognize the limit of their performance so that they contribute to the process. (D.9.1)

It was also reported the difficulty of communication that occurs between PC professionals and assistants, which can cause intense suffering to patients:

The most striking situation I have ever witnessed was a 44-year-old girl with cervical cancer, who discovered her diagnosis during pregnancy. She chose not to interrupt pregnancy, chemotherapy was started, she had a miscarriage, a hysterectomy was performed. One year later, she presented recurrence, with radical surgery being indicated, but she refused, opted for palliative sedation, being referred to home care (PIDI). On the day of her hospitalization, an assistant team was contacted about the patient's wishes. The team took 30 days to request this referral. As soon as the (palliative care) team arrived, the patient asked that she would like to die in peace, that she couldn't take any more suffering. Only then were futile measures suspended and exclusive palliative care started and, later, palliative sedation. (A.2.1)

\section{DISCUSSION}

Effective communication acts as an instrument to approach AVD, and needs to be constantly improved so that professionals can perceive beyond what is being said in words. Moreover, professionals cannot forget that they do not treat a disease, but a sick person, who needs an individual clinical approach that allows the discussion of a care plan for patients and their family, involving them in the decision-making process ${ }^{(16)}$.

AVD approach in the family context can be permeated by a situation of conflict, especially in view of the possibility of imminent loss of a loved one. The family takes on numerous responsibilities in therapeutic efforts, being perceived as indispensable in $P C^{(17)}$, but the fear of guilt for not investing in the family in the search for a cure is one of the factors that limit the practice of AVD ${ }^{(18)}$.

There is a need to expand communication between the team, family members and patients regarding their desires and desires, because the family's setback as to what was expressed generates limitation in the medical team in attending what was manifested ${ }^{(18)}$. For this reason, the elaboration of AVD with the appointment of a representative acts in the possibility of guaranteeing that the patients' requests are respected by the subjects involved ${ }^{(19)}$.

The PC team acts in a multidisciplinary manner, performing individual evaluation of each patient and establishing their conducts according to the diagnosis, prognosis, desires and needs encountered. Discussion about terminality should be inserted in spaces such as teaching and health care, in order to support the familiarization of professionals with the theme, who can transform the differentiated approach as a basis for modifying the experience and acceptance of death on the part of the population ${ }^{(19)}$.

With regard to individual performance, nursing has established itself as the category that remains the longest with patients, developing deep communication, which enables a relevant role in the guidance, reflection and discussions that involve AVD due to its interaction with patients, family and multidisciplinary team ${ }^{(20)}$. A study indicated that documents that record patients' physical symptoms are commonly found, but when the involvement of nurses specialized in PC occurs, the psychological and spiritual problems of patients are more frequently addressed ${ }^{(21)}$, which directs to comprehensive care of individuals.

The cycle of communication with patients inserts the contextualization of the role played by family members, who face conflicts when they need to respect the wishes of their loved one, who oppose their own will. Communication is fundamental to the approach of AVD, and its elaboration acts as a support in the dialogue about end-of-life care ${ }^{(13)}$. Insertion of patients, family members and professionals in the context of terminality is a way to provide assurance and fulfillment of patients' wills, in addition to avoiding obstinate behaviors, which are often employed due to the fear of performing a sincere dialogue about the situation experienced ${ }^{(18)}$.

Formalization regarding the registration of AVD in the medical record acts as the main tool for describing the patient's clinical situation. According to CFM Resolution 1995/2012, physicians must register in the medical records the AVD communicated by patients. In Brazilian legislation, there is still no standard document for the formalization of AVD, since it is still a subject under discussion in bills. Only one PC team reported the use of the POLST questionnaire as a standard form for recording patients' AVD. POLST permeates the path of complex decisions, allowing for a direct dialogue regarding the patient's desire or setbacks in relation to resuscitation, hospitalization and mechanical ventilation ${ }^{(22)}$.

On the other hand, the approach to desires and wants through the use of a form ready to be filled in can be perceived as an administrative task, not encouraging patients to seek personal reflection, which would only be possible through the writing of their AVD $^{(23)}$.

The use of messaging applications has become a tool of extensive use for the transfer of information between people, and not different, health professionals have established these applications also as a way of dialoguing about clinical cases. It should be noted that only patients can authorize the transfer of information from their medical records, and given the alarming emergence of instant messaging applications, it is necessary to reflect the ethical aspect of using this alternative ${ }^{(24)}$.

The messages described in the application are understood as an extension of patients' medical records, and its content may be subjected to ethical analysis regarding professional secrecy described in the current medical code of ethics. Seeking to intervene in this context, CFM approved Resolution 14/2017, which allows the use of messaging applications as a means of communication between physicians and patients or in closed groups of specialists or the clinical staff of an institution, with a private character to send data and discuss doubts except the confidential nature and prohibition of circulation of information outside the limits of the group, even with other professionals ${ }^{(25)}$.

The printed delivery of AVD for patients to use in later appointments is a way of seeking that their autonomy, desires and wishes are respected by all professionals who participate in their care, regardless of whether they work in PC teams or not. A study found 
that patients who were transferred or treated by teams that did not have access to their AVD had their wishes unfulfilled ${ }^{(13)}$. Thus, the content of an AVD needs to be accessible to the healthcare professionals involved at any time or location ${ }^{(21)}$.

Due to the inexistence of current legislation that subsidizes the use of AVD, the PC team professionals encourage their registration at the registry office as a legal support in the face of conflicts and as a way of seeking formal recognition of their autonomy. There is no need to formalize AVD in notary's office, but it should be considered that its registration makes the document easy to access and rescue. Furthermore, it is a way to ensure more safety at the will expressed by patients ${ }^{(26)}$.

AVD approach can be performed by palliative professionals, or not, which implies divergences in the conducts established in the different teams of PC participating in the study. The understanding that AVD approach should be made by the consulting PC team allows the familiarization of this with the process of human finitude makes it more tenuous and with positive possibilities of conducts that respect the requests of patients.

On the other hand, assistants' approach to AVD can occur superficially or not at all, anchored in aspects such as ignorance about the theme and fear of legal implications ${ }^{(10)}$ considering their non-palliative training. Moreover, studies indicate that knowledge and experience in the use of AVD are the factors that influence the decision regarding patients' wishes and desires, contributing to a higher acceptance rate by medical professionals ${ }^{(27)}$.

Using accessible language by health professionals in the exercise of informing patients about what is relevant in their health situation allows their decisions to be made consciously ${ }^{(10)}$, a characteristic that is inherent to the practice of PC. However, most health professionals, specifically physicians and assistant nurses, do not adequately inform patients about what ADV is about despite recognizing its importance ${ }^{(28)}$.

The lack of discussion about AVD with patients may be a consequence of the difficulty that professionals face when caring for those who are experiencing their terminality ${ }^{(29)}$. This data was corroborated by the report of the study participants regarding the disrespect to the wishes expressed by assisting teams, which highlights the need for a broad discussion of the relevance of PC and AVD. The commitment of health professionals must be continuous regarding the idea that the patients' autonomy is present even when he becomes unable to decide ${ }^{(19)}$.

Difficulty communication among the PC team professionals and assistant team professionals is a relevant factor that acts negatively in respecting the patients' autonomy and enabling AVD. The assistant team that is involved in care and seeks information with the PC team regarding the registered AVD and understands their choices and starts to assist in their implementation. Therefore, educating the health teams through training became a need that directly subsidizes the increase in the number of completed $A V D^{(30)}$.

\section{Study limitations}

This study was carried out with the PC teams registered on the website of the Brazilian National Academy of Palliative Care in the period of definition of the study subjects, being a specific sample, which does not allow the generalization of its results.
Scarce scientific studies in Brazil on AVD made it difficult to make comparisons between the results of the research and the reality experienced by the PC team professionals who work in other institutions or even in other contexts.

\section{Contributions to public policies}

This study is relevant to public policies, since research of this nature can contribute to the discussion about the acceptance of patients' AVDs as well as policies that enable the practice of PC.

\section{FINAL CONSIDERATIONS}

The PC team professionals' approach ADV through the use of tools such as effective communication and the establishment of a bond of trust with patients and family members, in addition to sensitive listening. When patients understand their health condition, the prognosis and therapeutic possibilities are clarified, increasing the chances of a dignified and less suffered death.

AVD registry takes place primarily in the medical record, which acts as an important legal support in case of doubts regarding the conduct performed during hospitalization. However, the fact that there is no standard document for AVD formulation in most institutions makes it difficult for professionals who are not part of the PC teams to access it, so the printed delivery of AVD and the incentive to register is often carried out in notary's office as a way to try to ensure that patients have their wishes respected in later appointments.

PC team preparation suggests that the current model of health care is an obstacle faced, still based on the paternalistic model in which professionals are the holders of knowledge and responsible for deciding what is best for the patient. Difficulty communication with the assisting team professionals who are unaware of the objectives of PC and organize their conduct disregarding what was requested by patients in the registered AVD are factors that can be modified if these themes are inserted in the discussions in the academic environment.

Professionals who perform care in order to offer quality of life and respect for the autonomy of patients understand that death is part of the life cycle and enable the experience of this moment as a natural process. They also enable the perception of the importance of philosophy PC with regard to approach and implementation of AVD.

AVD encourage a frank dialogue between patients and their family. AVD preferably should not be written only when the person is in the final stage of life, on the contrary, their discussion allows a deeper communication between the subjects involved and talk about the wishes and desires outside a context with emotional overload increase the chances of respecting what was requested.

However, considering that AVD are mostly discussed when patients are already in an advanced stage of illness or suffering, the presence of a professional or even a team, palliative or not, familiar with the theme, helps in organizing the process with minimization of conflicts. In this context, there is a need for further studies that address the relationship between AVD and $P C$, especially with regard to the facilities and difficulties encountered by PC professionals in the process of implementing the patients' AVD. 


\section{REFERENCES}

1. Cogo SB, Lunardi VL. Advance directives: a documentary analysis in the global context. Texto Contexto Enferm. 2018;27(3):e1880014. doi: 10.1590/0104-070720180001880014

2. Nickel L, Oliari LP, Vesco SNP, Padilha MI. Research groups in palliative care: the brazilian reality from 1994 to 2014. Esc Anna Nery. 2016;20(1):70-6. doi: 10.5935/1414-8145.20160010

3. World Health Organization. Palliative Care [Internet]. 2017 [cited 2019 Apr 10]. Available from: http://www.who.int/mediacentre/factsheets/ fs402/en/

4. Ministério da Saúde (BR). Resolução n. 41, de 31 de outubro de 2018. Dispõe sobre as diretrizes para a organização dos cuidados paliativos, à luz dos cuidados continuados integrados, no âmbito Sistema Único de Saúde. Diário Oficial da União, Brasília, 23 nov. 2018 . Seção 1, p.276

5. Governo do Estado do Rio Grande do Sul. Lei n. 15.277, de 31 de janeiro de 2019. Institui a política estadual de cuidados paliativos e dá outras providências. Diário Oficial da União, Rio Grande do Sul, 31 jan. 2019.

6. Gomes ALZ, Othero MB. Cuidados paliativos. Estud Av [Internet]. 2016 [cited 2019 Apr 10];30(88):155-66. doi: 10.1590/ S0103-40142016.30880011

7. Gulini JHMB, Nascimento ERP, Moritz RD, Vargas MAO, Matte DL, Cabral RP. Predictors of death in an Intensive Care Unit: contribution to the palliative approach. Rev Esc Enferm USP. 2018;52:e03342. doi: 10.1590/S1980-220X2017023203342

8. Gomes BMM, Salomão LA, Simões AC, Rebouças BO, Dadalto L, Barbosa MT. Advance directives in geriatric medicine. Rev Bioét 2018;26(3):429-39. doi: 10.1590/1983-80422018263263

9. Dadalto L. Distortion on living will in Brazil (or why it is necessary to talk about a prior declaration of will of terminal patient). Rev Bioét Derecho [Internet]. 2013 [cited 2019 Apr 10];28:61-71. Available from: http://scielo.isciii.es/pdf/bioetica/n28/articulo5.pdf

10. Moreira MADM, Costa SFG, Cunha MLDM, Zaccara AAL, Negro-Dellacqua M, Dutra F. Physician's perceptions for including living will in medical practice. Rev Bioét. 2017;25 (1):168-78. doi: 10.1590/1983-804222017251178

11. Conselho Federal de Medicina (CFM). Resolução no. 1.995, 9 de agosto de 2012. Dispõe sobre as diretivas antecipadas de vontade dos pacientes [Internet]. Diário Oficial da União: República Federativa do Brasil; 2012 [cited 2019 Apr 10] Aug 31 Seção 1. Available from: http:// www.portalmedico.org.br/resolucoes/CFM/2012/1995_2012.pdf

12. Central Notarial de Serviços Eletrônicos Compartilhados(CENSEC). Relatório estatístico acerca de atos inerentes a Diretivas Antecipadas de Vontade. 2018.

13. Jhonson CE, Singer R, Masso M, Sellars M, Silvester W. Palliative care health professionals' experiences of caring for patients with advance care directives. Australian Health Rev. 2015;9:154-9. doi: 10.1071/AH14119

14. Queiroz TA, Ribeiro ACM, Guedes MVC, Coutinho DTR, Galiza FT, Freitas MT. Palliative care to the elderly in intensive care: the perspective of the nursing team. Texto Contexto Enferm. 2018;27(1):e1420016. doi: 10.1590/0104-07072018001420016

15. Moraes R, Galiazzi MC. Análise Textual Discursiva. 2 ed. Editora Unijuí. 2013.

16. Pais C, Silva R, Carvalho S, Morais A. A good death: to recognize the end-of-life in time. Rev Medic Interna. 2019;26(3):238-46. doi: 10.24950/ rspmi/Revisao/253/18/3/2019

17. Cogo SB, Lunardi VL, Quintana AM, Girardon-Perlini NMO, Silveira RS. Challenges to implementation of advance directives of will in hospital practice. Rev Bras Enferm. 2016;69(6):969-76. doi: 10.1590/0034-7167-2016-0085

18. Cogo SB, Lunardi VL. Anticipated directives and living will for terminal patients: an integrative review. Rev Bras Enferm. 2015;68(3):464-74. doi: 10.1590/0034-7167.2015680321i

19. Cassol PB, Quintana AM, Velho MTA. Anticipated policy will: perception of nursing staff of blood-oncology. J Nurs Health[Internet]. 2015 [cited 2019 Apr 10];5(1):04-13. Available from: http://docs.bvsalud.org/biblioref/bdenf/2015/bde-31695/bde-31695-536.pdf

20. Kok M, Werff GFMV, Geerling Jl, Ruivenkamp J, Groothoff W, Velden AWGV et al. Feasibility of hospital-initiated nonfacilitator assisted advance care planning documentation for patients with palliative care needs. BMC Palliat Care. 2018;17(7). doi: 10.1186/s12904-018-0331-3

21. Abbott J. The POLST Paradox: opportunities and challenges in honoring patient end-of-life wishes in the Emergency Department. Ann Emerg Med. 2018;1-8. doi: 10.1016/j.annemergmed.2018.10.021

22. Trarieux-signol S, Bordessoule D, Ceccaldi J, Malak S, Polomeni A, Fargeas JB, et al. Advance directives from haematology departments: the patient's freedom of choice and communication with families: a qualitative analysis of 35 written documents. BMC Palliat Care. 2018;17(10):1-12. doi: 10.1186/s12904-017-0265-1

23. Grinberg M. Bioethics and Texting Using WhatsApp Always Online and in Hand. Arq Bras Cardiol. 2018;31(3):126-129. doi: $10.5935 / 2318-8219.20180021$

24. Conselho Federal de Medicina (BR). Resolução no 14, de 27 de abril de 2017. Dispõe sobre o uso do whatsapp no ambiente hospitalar [Internet]. Diário Oficial da União: República Federativa do Brasil; 27 Apr 2017 [cited 2019 Apr 30]. Available from: https://sistemas.cfm.org. br/normas/visualizar/pareceres/BR/2017/14 
25. Crippa A, Feijó AGS. The record of Advance Directive of Will: opinion of notaries of Porto Alegre city/RS. Mundo Saúde [Internet]. 2016 [cited 2019 Apr 10];40(2):257-266. doi: 10.15343/0104-7809.20164002257266

26. Arruda LM, Abreu KPB, Santana LBC, Sales MVC. Variáveis que influenciam na decisão médica frente a uma Diretiva Antecipada de Vontade e seu impacto nos cuidados de fim de vida. Einstein (São Paulo) [Internet]. 2020 [cited 2020 Mar 19];18:1-8. doi: 10.31744/ einstein_journal/2020RW4852

27. Pérez M, Herreros B, Martín MD, Molina J, Kanouzi J, Velasco M. Do spanish hospital professionals educate their patients about advance directives? a descriptive study in a University hospital in Madrid, Spain. J Bioeth Inq. 2016;13:295-303. doi: 10.1007/s11673-016-9703-7

28. Monteiro RSF, Silva Jr AG. Advance directive: historical course in Latin America. 2019;27(1):86-97. doi: 10.1590/1983-80422019271290

29. Tully, J. Advance care planning: meeting a crucial need. Nurs. 2018;48(11):63-66. doi: 10.1097/01.NURSE.0000546456.63746.1b 